\title{
PENGARUH KUALITAS PELAYANAN ADMINISTRASI, SARANA PRASARANA, DAN PERILAKU PEGAWAI TERHADAP KEPUASAN MASYARAKAT PEMOHON E-KTP DAN AKTE KELAHIRAN PADA DINAS KEPENDUDUKAN DAN CACATAN SIPIL KABUPATEN BIREUEN
}

\author{
Win Konadi $^{\left.1^{*}\right)}$ dan Syahniar ${ }^{2)}$ \\ 1, Dosen FE Universitas Almuslim Bireuen \\ 2 Pegawai Dinas Kependudukan dan Catatan Sipil Kabupaten Bireuen \\ *) email: winmanan1964@gmail.com
}

DOI:

https://doi.org/10.55178/idm.v2i3.209

ABSTRACT

Article history

Received:

March 5, 2021

Revised:

March 10, 2021

Accepted:

March 12, 2021

Page:

$1-11$

Kata kunci:

Service,

Infrastructure

Employee Behavior,

Community

Satisfaction,

e-KTP and Birth

Certificate
This study aims to assess and measure the magnitude; 1) The effect of the service system on the community satisfaction of $e-K T P-e$ applicants and birth certificates, 2) the influence of infrastructure on the community satisfaction of eKTP-e applicants and birth certificates, 3) the effect of service employee behavior on community satisfaction with e-KTP and the applicant for a birth certificate, and 4) the influence of the service system, facilities, and employee behavior on the community satisfaction of applicants for KTP-el and birth certificates at the Civil Service Population and Civil Disability Service. Bireuen District. With the research object is the people of Bireuen Regency who submitted and made El-KTP and birth certificates as many as 70 samples. With a path analysis approach. The results showed that; A). There is a direct and indirect effect of service quality factors on the satisfaction of the community managing and making KTP-e and child birth certificates by $33.58 \%$. b). The magnitude of the influence of service facilities and infrastructure factors on the satisfaction of the people who care for and make e-KTPs and birth certificates for children is $16.13 \%, c)$. And the influence of employee behavior factors on community satisfaction who care for and make e-KTPs and birth certificates for children at the Population and Civil Registry Office of Bireuen Regency is $20.89 \%$. Based on the size of the determination coefficient of 0.705 , it explains that the contribution of the aspects of service quality, service facilities and infrastructure and employee behavior to community satisfaction at the Population and Civil Registry Office of Bireuen Regency is 70.5\%. Meanwhile, the remaining role of the variable that was not examined was $29.5 \%$, indicating that there are other factors that can influence the variable of community satisfaction.

\section{Pendahuluan (Introduction)}

Masa depan bangsa dan keunggulan bangsa, Dalam penyelenggaraan pemerintahan negara, keberadaan birokrasi publik senantiasa terdapat baik di tingkat nasional maupun lokal. Keberadaan birokrasi yang dapat memberikan pelayanan publik yang berkualitas adalah harapan masyarakat. Memperhatikan bahwa birokrasi merupakan salah satu komponen yang berperan dalam administrasi pemerintahan, maka kesuksesan otonomi daerah bergantung pada kualitas pelayanan publik yang disajikan oleh birokrasi, khususnya Pemerintah Daerah Kabupaten/Kota.

Dalam konteks era desentralisasi ini, pelayanan publik seharusnya menjadi responsif terhadap kepentingan publik. Paradigma pelayanan publik berkembang dari pelayanan yang sifatnya sentralistik ke pelayanan 
yang lebih memberikan fokus pada pengelolaan yang berorientasi kepuasan pelanggan (Customer-Driven Government) dengan ciri-ciri (Mohamad, 2003):

a) Lebih memfokuskan diri pada fungsi pengaturan melalui berbagai kebijakan yang memfasilitasi berkembangnya kondisi kondusif bagi kegiatan pelayanan kepada masyarakat,

b) Lebih memfokuskan diri pada pemberdayaan masyarakat sehingga masyarakat mempunyai rasa memiliki yang tinggi terhadap fasilitas-fasilitas pelayanan yang telah dibangun bersama,

c) Menerapkan sistem kompetisi dalam hal penyediaan pelayanan publik tertentu sehingga masyarakat memperoleh pelayanan yang berkualitas,

d) Terfokus pada pencapaian visi, misi, tujuan dan sasaran yang berorientasi pada hasil (Outcomes) sesuai dengan masukan yang digunakan,

e) Lebih mengutamakan apa yang diinginkan oleh masyarakat,

f) Pada hal tertentu pemerintah juga berperan untuk memperoleh pendapat dari masyarakat dari pelayanan yang dilaksanakan,

g) Lebih mengutamakan antisipasi terhadap permasalahan pelayanan,

h) Lebih mengutamakan desentralisasi dalam pelaksanaan pelayanan, dan

i) Menerapkan sistem pasar dalam memberikan pelayanan.

Dalam kaitan dengan penyelenggaraan pemerintahan, birokrasi sebagai ujung tombak pelaksana pelayanan publik mencakup berbagai program pembangunan dan kebijakan pemerintah.Seperti halnya pengaturan tentang administrasi kependudukan yang salah satu diantaranya yakni Akta Kelahiran melalui perundangundangan administrasi kependudukan yang selama ini tidak sesuai dengan tuntutan pelayanan administratif yang tertib dan tidak diskriminatif.

Seiring dengan itu, pemerintah menerbitkan UU No. 23 Tahun 2006 tentang administrasi kependudukan yang menjadi pegangan semua penyelenggara negara yang berhubungan dengan kependudukan. Kemudian juga keluar Undang-Undang Republik Indonesia Nomor 24 Tahun 2013 Tentang Perubahan Atas UndangUndang Nomor 23 Tahun 2006 Tentang Administrasi Kependudukan, dengan meninmbang bahwa dalam rangka peningkatan pelayanan Administrasi Kependudukan sejalan dengan tuntutan pelayanan Administrasi Kependudukan yang profesional, memenuhi standar teknologi informasi, dinamis, tertib, dan tidak diskriminatif dalam pencapaian standar pelayanan minimal menuju pelayanan prima yang menyeluruh untuk mengatasi permasalahan kependudukan, perlu dilakukan penyesuaian terhadap beberapa ketentuan dalam Undang-Undang Nomor 23 Tahun 2006 tentang Administrasi Kependudukan.

Dalam konteks penelitian ini pelayanan publik ditekankan pada kualitas pelayanan publik yang ada pada Dinas Kependudukan dan Catatan Sipil, yang merupakan unsur pelaksana Pemerintah Kabupatem Bireuen di bidang Kependudukan dan Catatan Sipil sesuai dengan kewenangan Pemerintah daerah serta Peraturan Perundang-undangan yang berlaku. Dinas Kependudukan dan Catatan Sipil dipimpin oleh seorang Kepala Dinas yang berada di bawah Bupati dan bertanggung jawab kepada Bupati melalui Sekretaris Daerah serta mempunyai tugas melaksanakan kewenangan Pemerintah di bidang Kependudukan dan Catatan Sipil serta tugas lain yang diberikan oleh Bupati.

Dalam hal penyelenggaraan pelayanan publik, orientasi pada kekuasaan yang amat kuat selama ini telah membuat birokrasi menjadi semakin jauh dari misinya untuk memberikan pelayanan publik. Birokrasi dan para pejabatnya lebih menempatkan dirinya sebagai penguasa dari pada pelayan masyarakat. Akibatnya sikap dan perilaku birokrasi dalam penyelenggaraan pelayanan publik cenderung mengabaikan aspirasi dan kepentingan masyarakat. Berkembangnya Budaya Paternalistik ikut memperburuk sistem pelayanan publik melalui penempatan kepentingan elite politik dan birokrasi sebagai variabel yang dominan dalam penyelenggaraan pelayanan publik (Dwiyanto, 2006, 2).

Dalam hal yang terjadi di daerah, seperti halnya di Kabupatem Bireuen dimasa lalu, birokrasi yang dimaksudkan untuk melaksanakan tugas-tugas umum pemerintahan dan pembangunan tersebut, seringkali diartikulasikan berbeda oleh masyarakat. Birokrasi di dalam menyelenggarakan tugas pemerintahan dan pembangunan (termasuk di dalamnya penyelenggaraan pelayanan publik) diberi kesan sebagai proses kontraproduktif dalam penyelesaian masalah. Akibatnya, birokrasi selalu mendapatkan citra negatif yang tidak menguntungkan bagi perkembangan birokrasi itu sendiri, khususnya dalam hal pelayanan publik, seperti yang diteliti oleh Negoro (2004:4).

Pada saat ini masyarakat semakin sadar akan apa yang menjadi hak dan kewajibanya sebagai warga Negara. Masyarakat semakin berani untuk untuk mengajukan tuntutan, keinginan dan aspirasinya kepada pemerintah. Dalam kondisi masyarakat seperti ini pelayanan publik harus dapat memberikan suatu pelayanan yang efektif. Pelayanan harus dapat diselesaikan dalam waktu yang telah di tentukan oleh unit 
penyelengara pelayanan dan informasi yang jelas dalam hal persyaratan untuk dapat mendapatkan pelayanan tersebut dengan prosedur pelayanan yang mudah dipahami tidak berbelit serta perlu adanya kepastian biaya pelayanan. Pelayanan publik harus sesuai dengan apa yang di butuhkan masyarakat yaitu pemerintah harus mampu memenuhi keinginan dan kebutuhan pelayanan dengan menyediakan pelayanan yang tepat. Berdasarkan keputusan Menteri Pendayagunaan Aparatur Negara No. 62 tahun 2003, tentang pedoman umum penyelengaraan Pelayanan Publik, disebutkan bahwa pelayan publik oleh pemerintah di bedakan menjadi tiga kelompok pelayanan, yaitu: Pertama, kelompok layanan yang menghasilkan bentuk dokumen resmi yang di butuhkan oleh publik; Kedua, kelompok layanan yang menghasilakan bentuk atau jenis barang yang di gunanakan oleh publik; Ketiga, kelompok layanan yang menghasilkan berbagai bentuk jasa yang di butuhkan. Pelayanan publik oleh birokrasi seharusnya di gerakan oleh visi dan misi pelayanan, namun pada kenyataanya justru digerakan oleh peraturan dan anggaran yang tidak dimengerti karena tidak disosialisasikan secara transparan. (Kepmenpan Nomor 63 Tahun 2003).

Layanan publik dalam hal ini dipahami sebagai segala kegiatan yang dilaksanakan Dinas Kependudukan dan Catatan Sipil Kabupaten Bireuen dalam rangka pemberian layanan penerbitan Kartu Tanda Keluarga (KK), Kartu Tanda Penduduk (KTP) dan Akta Kelahiran. Dalam hal ini, paling tidak terdapat tiga pelaku yaitu: pembuat kebijakan, penyedia/pelaksana layanan publik, dan penerima layanan. Dalam system pemerintahaan, dominan perumus dan pelaksana layanan publik dilakukan oleh pemerintah, dan masyarakat sebagai penerima.

Pelayanan publik oleh birokrasi seharusnya digerakkan oleh visi dan misi pelayanan, namun pada kenyataannya justru digerakkan oleh peraturan dan anggaran yang tidak dimengerti oleh publik karena tidak disosialisasikan secara transparan (hal ini ditemukan oleh hasil penelitian Dwiyanto, 2002:84). Dilihat dari sisi pola penyelenggaraannya, pelayanan publik masih memiliki berbagai kelemahan antara lain; a. Kurang responsif. b. Kurang informatif. c. Kurang accessible. d. Kurang koordinasi. e. Birokratis. f.Kurang mau mendengar keluhan/saran/aspirasi masyarakat. dan g. Inefisien.

\section{Tinjauan Literatur (Literature Review)}

\section{a. Kualitas Pelayanan}

Kotler \& Keller (2013) menyatakan bahwa: “A service is any act or performance one party can offer to another that is essentially intangible and does not result in the ownership of anything”. Dari definisi ini dapat diartikan bahwa pelayanan adalah setiap tindakan atau kegiatan yang dapat ditawarkan oleh suatu pihak kepada pihak lain yang pada dasarnya tidak berwujud dan tidak mengakibatkan kepemilikan apapun.

Sedangkan menurut Moenir (2010 : 26) pelayanan adalah kegiatan yang dilakukan oleh seseorang atau sekelompok orang dengan landasan faktor materi melalui sistem, prosedur dan metode tertentu dalam rangka usaha memenuhi kepentingan orang lain sesuai dengan haknya. Pelayanan hakikatnya adalah serangkaian kegiatan, karena itu pelayanan merupakan sebuah proses. Sebagai proses, pelayanan berlangsung secara rutin dan berkesinambungan, meliputi seluruh kehidupan orang dalam masyarakat. Sedangkan menurut Groonros (1990:27) dalam Ratminto dan Atik (2005:2) pelayanan adalah suatu aktivitas atau serangkaian aktivitas yang bersifat tidak kasat mata (tidak dapat diraba) yang terjadi sebagai akibat adanya interaksi antara konsumen dengan karyawan atau hal-hal lain yang di sediakan oleh perusahaan pemberi pelayanan yang dimaksudkan untuk memecahkan permasalahan konsumen atau pelanggan.

Tjiptono (2012) menyatakan bahwa dalam literatur manajemen dijumpai setidaknya empat lingkup definisi konsep pelayanan (service), yaitu: 1) Pelayanan menggambarkan berbagai sub-sektor dalam kategorisasi aktifitas ekonomi, seperti transportasi, finansial, perdagangan ritel, personal services, kesehatan, pendidikan, dan layanan publik. 2) Pelayanan dipandang sebagai produk Intangible yang hasilnya lebih berupa aktifitas ketimbang objek fisik, meskipun dalam kenyataannya bisa saja produk fisik dilibatkan. 3).Pelayanan merefleksikan proses yang mencakup penyampaian produk utama, interaksi personal, kinerja, serta pengalaman layanan. 4) Pelayanan dapat juga dipandang sebagai sistem yang terdiri dari dua komponen utama, yakni service operations yang kerapkali tidak tampak atau diketahui keberadaannya oleh pelanggan (back office atau backstage) dan service delivery yang biasanya tampak (visible) atau diketahui keberadaannya oleh pelanggan (front office atau frontstage).

Gronroos dalam Tjiptono (2012) menyatakan bahwa pelayanan merupakan proses yang terdiri atas serangkaian aktifitas intangible yang biasa (namun tidak harus selalu) terjadi pada interaksi antara pelanggan dan karyawan, jasa dan sumber daya, fisik atau barang, dan sistem penyedia jasa, yang disediakan sebagai solusi atas masalah pelanggan. 
Dari definisi diatas dapat disimpulkan bahwa pelayanan (service) merupakan kegiatan tidak berwujud yang dapat dirasakan dengan tujuan untuk memenuhi kebutuhan dan keinginan pelanggan yang menimbulkan kepuasan berdasarkan perbandingan antara persepsi dan harapan mereka dan tidak mengakibatkan kepemilikan apapun.

Dalam hal kantor pemerintah, dikenal dengan pelayanan publik, yang merupakan bagian integral dari mekanisme sistem pemerintahan di samping fungsi. Masalah pokok yang menjadi perhatian kita adalah bahwa suatu pelayanan itu terdiri yang terdiri dari penyelenggaraan dan penerimaan layanan (Costumer). Makin luasnya lingkup pelayanan dan jasa-jasa publik (public service) yang dikelola pemerintah meliputi segenap aspek kehidupan masyarakat, hendaknya diikuti oleh kualitas pelayanan yang baik. Misalnya pada Dinas Kependudukan dan Cacatan Sipil, ketika berbicara pelayanan, sebenarnya masyarakat sudah memerlukan pelayanan publik ketika seseorang berada dalam kandungan ketika hendak diperiksa oleh dokter pemerintah, setelah lahir mengurus akta kelahiran, saat mencapai usia 17 tahun memerlukan identitas dan (KTP), menjalani pendidikan, mendapatkan macam-macam perijinan dan sebagainya sampai seseorang meninggal dunia membutuhkan surat pengantar untuk penguburan ataupun surat kematian/akta kematian (Zaini Rohmad.dkk. 2014; 2015)

Menurut Wyckof dan Lovelock (dalam Purnama, 2006) memberikan pengertian kualitas pelayanan sebagai tingkat kesempurnaan tersebut untuk memenuhi keinginan konsumen. Sedangkan menurut Parasuraman, et.al (dalam Kotler, 2003) bahwa kualitas layanan merupakan perbandingan antara layanan yang dirasakan dengan kualitas layanan yang diharapkan konsumen.

Sedangkan menurut Kasmir dalam Pasolong (2011:133) mengatakan bahwa pelayanan yang baik adalah kemampuan seseorang dalam memberikan pelayanan yang dapat memberikan kepuasan kepada pelanggan dengan standar yang telah ditentukan.

Menurut Zeithhaml-Parasurman-Berry dalam Pasolong (2011:135) untuk mengetahui kualitas pelayanan yang dirasakan secara nyata oleh konsumen, terdapat indikator ukuran kepuasan konsumen yang terletak pada lima dimensi kualitas pelayanan menurut apa yang dikatakan konsumen. Kelima dimensi tersebut, yaitu:

1. Tangibles (bukti langsung). Kualitas pelayanan berupa sarana fisik perkantoran, komputerisasi administrasi, ruang tunggu, tempat informasi.

2. Reliability (kehandalan). Kemampuan dan keandalan untuk menyediakan pelayanan yang terpercaya.

3. Responsivess (daya tanggap). Kesanggupan untuk membantu dan menyediakan pelayanan secara cepat dan tepat, serta tanggap terhadap keinginan konsumen.

4. Assurance (jaminan). Kemampuan dan keramahan serta sopan santun pegawai dalam meyakinkan kepercayaan konsumen.

5. Empaty (empati). Sikap tegas tetapi penuh perhatian dari pegawai terhadap konsumen.

\section{b. Sarana Prasarana}

Untuk menciptakan keberhasilan dalam bekerja, kantor harus menjamin dan menyediakan fasilitas-fasilitas yang menunjang keberhasilan karyawan dalam bekerja. Hal ini disebabkan karena tenaga kerja saja tidak cukup untuk melakukan sebuah kegiatan kantor, tetapi harus di dukung dengan adanya fasilitas agar pencapaian kerja karyawan sesuai dengan yang diinginkan. Fasilitas kantor ini terdiri dari dua yaitu sarana dan prasarana. Kondisi seperti ini sudah pasti akan menimbulkan keterlambatan dalam menginput dan mengeluarkan output data perusahaan baik negeri maupun swasta. Padahal dewasa ini di perlukan kecepatan dan ketepatan dan hasil kualitas kerja yang maksimal dari kantor atau perusahaan. Maka dari itu, kantor atau perusahaan harus sangat memperhatikan tentang pentingnya sarana dan prasarana dengan kelengkapannya agar pencapaian kerja karyawan menghasilkan hasil yang sangat memuaskan.

Adapun fungsi dari fasilitas sarana kantor adalah: 1) Untuk menghemat secara fisik tenaga dan pikiran manusia dalam melakukan pekerjaannya 2) Mengurangi kebosanan dalam keletihan bekerja apabila harus mengerjakan pekerjaan yang berulang-ulang, dan 3) Menghemat waktu.

Pada dasarnya fungsi dari prasarana kantor adalah untuk memotivasi para pegawai agar mau bekerja dengan giat dan antusias untuk mencapai hasil yang optimal, dan menjadi pedoman atau acuan karyawan dalam bekerja seperti dengan adanya SOP/SPM. Dengan demikian dapat meningkatkan produktivitas pada suatu kantor tersebut. Produktivitas kerja karyawan sangat di dukung dengan adanya kelengkapan sarana dan prasarana kantor. 
Karena itu, sarana dan prasarana kantor sangat penting dalam proses pencapaian kerja karyawan karena sarana dan prasarana kantor sebagai hal atau aspek pendukung terciptanya kegiatan kantor yang produktif dan optimal. Sebagaimana disebutkan Djoyowirono (2005: 24) menyatakan bahwa: "fasilitas/sarana adalah alat yang diperlukan untuk menggerakkan kegiatan manajemen dalam rangka mencapai tujuan organisasi.

Kebutuhan Sarana Prasarana, terdiri atas a. Perangkat Keras (Data center, Data recovery center, dan perangkat pembaca data), b. Perangkat Lunak (Sistem pendukung layanan SIAK), c. Jaringan Komunikasi Data Sumber Daya Manusia (Operator, Tenaga ahli dan pengelola system sertifikasi elektronik), d. Pengamanan (Keamanan data, keamanan sistem dan keamanan dokumen ); dan Pengembangan dan Pemeliharaan (Penyediaan perangkat keras dan perangkat lunak yang dapat memenuhi perkembangan kebutuhan pelayanan Adminduk Daring), e) Gedung/Kantor, Gedung Arsip, Meja, Kursi, Filing dan Lemari arsip, Parkiran dan MCK.

\section{c. Perilaku Pegawai}

Pemerintah dan aparatur pemerintah yang menjaga kredibilitas dan kewibawaannya yang tinggi akan dihormati oleh masyarakat yang dilayaninya. Aparatur pemerintah yang memiliki etika dan moralitas yang tinggi dalam menjalankan tugasnya, tentu memiliki akuntabilitas dan penghormatan yang tinggi pula terhadap tuntutan aspirasi dan kepentingan masyarakat yang dilayani itu. Dalam pemerintahan yang demikian itu pula iklim keterbukaan, partisipasi aktif dan pemberdayaan masyarakat akan dapat terwujudkan, sebagai manifestasi dari gagasan yang dewasa ini mulai dikembangkan, yaitu kepemerintahan yang baik (good governance).

Pemahaman mengenai etika dan moralitas dalam pemerintahan merupakan kompetensi dasar yang penting dan strategis yang harus dimiliki dan dipraktekkan secara konsisten oleh setiap individu sebagai perilaku pegawai pemerintah selaku unsur aparatur Negara, abdi Negara dan abdi masyarakat dalam praktek penyelenggaraan pemerintahan, pembangunan dan pelayanan kepada masyarakat. Disamping perilaku pegawai yang mengedepankan etika dan moralitas, perlu adanya suatu strategi untuk berubah atau hanya dengan menetapkan sasaran-sasaran kinerja. Karena, perubahan adalah perlakuan terhadap orang-orang yang membiasakan terhadap kestabilan dan kontinuitas.

Soewarno (2006), menyatakan: "Perilaku ialah apa yang kita lakukan, bukan mengapa kita melakukan itu". Perilaku pegawai menurut Robins (2003) dalam buku Perilaku Organsasi yang diterjemahkan dalam bahasa Indonesia menjelaskan bahwa: "Perilaku pegawai merupakan suatu karakteristik dan tingkah laku yang terdapat dalam setiap individu atau suatu organisasi yang terdapat dinamika kepemimpinan. Perilaku pegawai meliputi kepribadian, harga diri, pemantauan diri, dan kecenderungan untuk menanggung resiko".

Perilaku pegawai lebih cenderung kepada pokok kepribadian, karena kepribadian menggambarkan perilaku seorang individu. Karakteristik mencakup perasaan malu, keagresifan, sikap patuh, kemalasan, ambisi, kesetiaan, dan sifat takut dan malu. Karakteristik ini bila diperagakan dalam sejumlah besar situasi, disebut ciri-ciri kepribadian. Semakin konsisten karakteristik itu dan semakin sering terjadi dalam berbagai situasi, maka disebut dengan perilaku. Karakteristik tersebut dapat bersifat positif dan negatif. Karakteristik yang bersifat positif akan menguntungkan bagi organisasi dalam mencapai tujuannya, namun sebaliknya karakteristik yang negatif akan merugikan bagi organisasi. Untuk itu karakteristik-karakteristik tersebut dapat dipengaruhi oleh sifat kepemimpinan seorang pemimpin atau atasan dalam menjalankan roda keorganisasiannya.

Penilaian perilaku kerja dalam Peraturan Pemerintah (PP) Nomor 46 Tahun 2011, meliputi aspek: a) Orientasi pelayanan, b) Integritas, c) Komitmen, d) Disiplin, e) Kerja sama, dan f) Kepemimpinan. Nilai perilaku kerja PNS dinyatakan dengan angka dan keterangan : a) 91 - 100 : Sangat baik, b) 76 - 90 : Baik, c) $61-75:$ Cukup, d) $51-60:$ Kurang, dan e) 50 - ke bawah : Buruk.

Ada empat indikator yang dapat digunakan untuk mengetahui perilaku kerja menurut Griffiths (2004,pp. 41-42), yaitu : 1) Social relationships (hubungan sosial), 2) Vocational skill (keahlian kejuruan). 3) Work motivation (motivasi kerja), dan 4) Initiative - confidence (inisiatif-percaya diri).

\section{d. Kepuasan Pengguna Jasa (Masyarakat)}

Kotler (dalam Rangkuti, 2006) secara umum kepuasan pengguna jasa adalah perasaan senang atau kecewa seseorang sebagai hasil dari perbandingan antara persepsi atau jasa layanan yang dirasakan dan diharapkan. Jika kinerja berada dibawah harapan, maka pengguna jasa tidak puas. Sedangkan jika kinerja memenuhi harapan, maka pengguna jasa layanan puas. 
Tjiptono (2007) mengungkapkan bahwa kepuasan pelanggan adalah respon pelanggan pada evaluasi persepsi terhadap perbedaan antara ekspektasi awal (standar kinerja tertentu) dan kinerja aktual produk sebagaimana dipersepsikan setelah konsumsi produk. Sementara itu, Engel, at.al (dalam Tjiptono, 2007) menyatakan bahwa kepuasan pelanggan merupakan evaluasi purnabeli dimana alternatif yang dipilih sekurang-kurangnya sama atau melampaui harapan pelanggan, sedangkan ketidakpuasan timbul apabila hasil tidak memenuhi harapan.

Secara umum, Kepuasan didefinisikan sebagai respon pengguna jasa terhadap kesesuaian antara tingkat kepentingan sebelumnya dan kinerja aktual yang dirasakan setelah pemakaian. Oleh karena itu, agar pelayanan dapat memuaskan masyarakat (publik), maka pegawai yang bertugas melayani harus memenuhi empat kriteria pokok menurut (Moenir, 2006) yaitu : 1) Tingkah laku yang sopan; 2) Cara menyampaikan sesuatu yang berkaitan dengan apa yang seharusnya diterima oleh orang yang bersangkutan; 3) Waktu menyampaikan yang tepat; dan 4) Keramah tamahan.

\section{Metode Penelitian (Methodology)}

\section{a. Metode dan Variabel Penelitian}

Metode penetian yang akan digunakan dalam penelitian ini adalah metode asosiatif dengan pendekatan kuantitatif. Metode asosiatif merupakan metode yang bermaksud untuk menjelaskan hubungan kausal dan pengaruh antara variabel-variabel melalui pengujian hipotesis. Menurut Sugiyono (2012:11) menyatakan bahwa pengertian asosiatif adalah Penelitian yang bertujuan untuk mengetahui pengaruh ataupun hubungan antara dua variabel atau lebih.

Desain penelitian ini adalah terdiri dari 3 (tiga) variabel independen yaitu Kualitas Pelayanan $\left(\mathrm{X}_{1}\right)$, Sarana Prasarana $\left(\mathrm{X}_{2}\right)$ dan Perilaku Pegawai $\left(\mathrm{X}_{3}\right)$ terhadap variabel Dependen yaitu Kepuasan Masyarakat $(\mathrm{Y})$..

Adapun variabel, dimensi dan indikator pengukurnya di definisikan berikut ini.

\section{Tabel 1. Operasional Variabel Penelitian}

\begin{tabular}{|c|c|c|}
\hline Variabel & Defenisi Konsep & Indikator \\
\hline $\begin{array}{l}\text { Kualitas } \\
\text { Pelayanan } \\
\left(\mathrm{X}_{1}\right)\end{array}$ & $\begin{array}{l}\text { Kualitas layanan merupakan perbandingan antara } \\
\text { layanan yang dirasakan dengan kualitas layanan } \\
\text { yang diharapkan konsumen. } \\
\text { Pelayanan yang baik adalah kemampuan } \\
\text { seseorang dalam memberikan pelayanan yang } \\
\text { dapat memberikan kepuasan kepada pelanggan } \\
\text { dengan standar yang telah ditentukan. } \\
\text { Sumber: Parasuraman, et.al (dalam Kotler, 2003) } \\
\text { Pasolong (2011:133) }\end{array}$ & $\begin{array}{l}\text { 1. Tangibles, } \\
\text { 2. Reliability, } \\
\text { 3. Responsivess, } \\
\text { 4. Assurance, } \\
\text { 5. Emphaty. } \\
\text { Sumber: } \\
\text { Zeithhaml-Parasurman-Berry dalam } \\
\text { Pasolong (2011:135) }\end{array}$ \\
\hline $\begin{array}{l}\text { Sarana Prasarana } \\
\left(\mathrm{X}_{2}\right)\end{array}$ & $\begin{array}{l}\text { Fasilitas/sarana adalah alat yang diperlukan untuk } \\
\text { menggerakkan kegiatan manajemen dalam rangka } \\
\text { mencapai tujuan organisasi. } \\
\text { Sumber: Djoyowirono }(2005: 24)\end{array}$ & $\begin{array}{l}\text { 1.Sarana: } \\
\text { a. Perangkat Keras (Data Center, Data } \\
\text { recovery center, dan perangkat } \\
\text { pembaca data) } \\
\text { b. Perangkat Lunak (SIAK) } \\
\text { c. SDM (Operator, Tenaga ahli, dan } \\
\text { pengelola system) } \\
\text { d. Pengamanan (Keamanan data, } \\
\text { keamanan sistem dan keamanan } \\
\text { dokumen), pengembangan dan } \\
\text { pemeliharaan (Penyediaan } \\
\text { Perangkat keras dan Perangkat } \\
\text { lunak yang dapat memenuhi } \\
\text { perkembangan kebutuhan } \\
\text { pelayanan Adminduk Daring) } \\
\text { 2.Prasarana: } \\
\text { a. Gedung/Kantor/ b. Gudang Arsip } \\
\text { c. Meja, Kursi, Filing, lemari arsip. } \\
\text { d. Parkiran dan e. MCK } \\
\text { (Permendagri } 7 \text { tahun 2019. Pasal 39) } \\
\text { (Moenir, 1992:119) }\end{array}$ \\
\hline $\begin{array}{l}\text { Perilaku Pegawai } \\
\left(\mathrm{X}_{3}\right)\end{array}$ & $\begin{array}{l}\text { Perilaku pegawai merupakan suatu karakteristik } \\
\text { dan tingkah laku yang terdapat dalam setiap } \\
\text { individu atau suatu organisasi yang terdapat }\end{array}$ & $\begin{array}{l}\text { a Orientasi pelayanan, } \\
\text { b Integritas, } \\
\text { c Komitmen, }\end{array}$ \\
\hline
\end{tabular}




\begin{tabular}{|c|c|c|}
\hline & $\begin{array}{l}\text { dinamika kepemimpinan. Perilaku pegawai } \\
\text { meliputi kepribadian, harga diri, pemantauan diri, } \\
\text { dan kecenderungan untuk menanggung resiko. } \\
\text { Sumber: Robins (2003) }\end{array}$ & $\begin{array}{l}\text { d Disiplin, } \\
\text { e Kerja sama, } \\
\text { f Kepemimpinan. }\end{array}$ \\
\hline $\begin{array}{l}\text { Kepuasan } \\
\text { Masyarakat } \\
\text { (Y) }\end{array}$ & $\begin{array}{l}\text { Kepuasan didefinisikan sebagai respon pengguna } \\
\text { jasa terhadap kesesuaian antara tingkat kepenti- } \\
\text { ngan sebelumnya dan kinerja aktual yang } \\
\text { dirasakan setelah pemakaian. Oleh karena itu, } \\
\text { agar pelayanan dapat memuaskan masyarakat/ } \\
\text { publik } \\
\text { Sumber: Moenir (2006) }\end{array}$ & $\begin{array}{l}\text { 1.Tingkah laku; } \\
\text { 2.Cara menyampai-kan; } \\
\text { 3.Waktu menyampaikan yang tepat; } \\
\text { 4.Keramah tamahan. } \\
\text { Sumber: Moenir (2006) }\end{array}$ \\
\hline
\end{tabular}

\section{b. Populasi dan Sampel Penelitian}

Populasi dalam penelitian ini adalah Masyarakat Pemohon KTP-el dan Akta Kelahiran pada Dinas Kependudukan dan Pencatatan Sipil Kabupaten Bireuen, yang dibatasi pada tahun 2010. Diambil sampel adalah sebagian dari populasi yang memiliki karakteristik yang sama dengan populasi. Sampel menurut Sugiyono (2013:115) adalah bagian dari jumlah dan karakteristik yang dimiliki oleh populasi. Yang menjadi sampel dalam penelitian ini adalah sebagaian masyarakat pemohon KTP-el dan Akta Kelahiran Dinas Kependudukan dan Pencatatan Sipil Kabupaten Bireuen yang berjumlah 75 orang.

\section{c. Alat Analisis}

Analisis jalur digunakan untuk mengetahui besarnya pengaruh suatu variabel terhadap variabel lainnya baik pengaruh langsung maupun tidak langsung. Langkah dalam melakukan analisis data dengan menggunakan analisis jalur sesuai dengan modifikasi dari Harun dalam Nirwana (2014:19-28). Besarnya pengaruh variabel bebas terhadap variabel terikat disebut koefisien jalur.

Menurut Pedhazur (1982) dalam Marwan Hamid, dkk (2019), bahwa tujuan analisis jalur adalah apakah model yang diusulkan cocok atau tidak dengan data, yaitu dengan cara membandingkan matriks korelasi teoritis dengan matriks korelasi empiris. Jika kedua matriks relatif sama, maka model dikatakan "cocok" atau fit.

Analisis jalur ialah suatu teknik untuk menganalisis hubungan sebab-akibat yang terjadi pada regresi berganda jika variabel bebasnya mempengaruhi variabel tergantungnya tidak hanya secara langsung, tetapi juga secara tidak langsung" (Robert D. Rutherford, 1993, dalam Marwan Hamid, dkk; 2019:10). Definisi lain mengatakan "Analisis jalur merupakan pengembangan langsung bentuk regresi berganda dengan tujuan untuk memberikan estimasi tingkat kepentingan (magnitude) dan signifikansi (significance) hubungan sebab-akibat hipotetikal dalam seperangkat variabel" (Paul Webley; 1997)

Menurut Marwan Hamid, dkk (2019:10), Model analisis jalur digunakan untuk menganalisis pola hubungan antar variabel dengan tujuan untuk mengetahui pengaruh langsung maupun tidak langsung seperangkat variabel bebas (eksogen) terhadap variabel terikat (endogen). Model analisis jalur yang dibicarakan adalah pola hubungan sebab-akibat. Oleh karena itu, rumusan masalah penelitian dalam kerangka analisis jalur hanya berkisar pada variabel bebas $\left(\mathrm{X}_{1}, \mathrm{X}_{2}, \ldots, \mathrm{X}_{\mathrm{k}}\right)$ yang berpengaruh terhadap variabel terikat $\mathrm{Y}$ atau berapa besar pengaruh kausal langsung, kausal tidak langsung, kausal total maupun simultan seperangkat variabel bebas $\left(\mathrm{X}_{1}, \mathrm{X}_{2}, \ldots, \mathrm{X}_{\mathrm{k}}\right)$ terhadap variabel terikat $\mathrm{Y}$.

Sebelum melakukan analisis, ada beberapa prinsip dasar atau asumsi yang mendasari analisis jalur, yaitu:

1. Pada model analisis jalur, hubungan antar variabel adalah bersifat linier, adaptif, dan bersifat normal.

2. Hanya sistem aliran kausal ke satu arah, artinya tidak ada arah kausalitas yang berbalik.

3. Variabel terikat (endogen), minimal dalam skala ukur interval dan ratio.

4. Menggunakan sampel probability sampling, yaitu teknik pengambilan sampel untuk memberikan peluang yang sama pada setiap anggota populasi untuk dipilih menjadi anggota sampel.

5. Variabel observasi diukur tanpa kesalahan (instrumen pengukuran valid danreliabel), artinya variabel yang diteliti dapat diobservasi secara langsung.

6. Model yang dianalisis dispesifikasikan (diidentifikasi) dengan benar berdasarkan teori-teori dan konsepkonsep yang relevan, artinya model teori yang dikaji atau diuji dibangun berdasarkan kerangka teoritis tertentu yang mampu menjelaskan hubungan kausalitas antar variabel yang diteliti.

(Marwan Hamid, dkk; 2019:12) 
Untuk dapat menggunakan alat analisis ini, dipastikan data memiliki skala ukur minimal interval. Juga syarat statistik regresi dan analisis jalur, terpenuhinya semua asumsi klasik, yakni normalitas, heterosidasitas, multikolinieritas.

\section{Hasil dan Pembahasan (Results and Discussion)}

\section{a. Karakteristik Responden}

Responden dalam penelitian ini berjumlah 75 warga masyarakat di Kabupaten Bireuen yang mengajukan dan mendapat pelayanan pembuatan KTP-El dan Akte Kelahiran selama tahun 2020. Dari sampel 75 orang yang dilakukan Penelitian ini, dapat di deskripsikan tentang Karakteristik responden berdasarkan jenis keperluannya (KTP-El dan Akte Kelahiran), berdasarkan jenis kelamin, pekerjaan, usia, dan tingkat pendidikannya.

Tabel 2.

Karakteristik Responden Berdasarkan Jenis Kelamin

\begin{tabular}{|c|c|c|}
\hline Karateristik & Jumlah (orang) & Persentase (\%) \\
\hline Keperluan : KTP & 32 & 42,67 \\
\hline Akte Kelahiran & 21 & 28,00 \\
\hline Kedua-nya & 22 & 29,33 \\
\hline Kelamin : Laki-laki & 32 & 42,67 \\
\hline Perempuan & 43 & 57,33 \\
\hline Usia $:$ Thn & 11 & 14,67 \\
\hline $20-29$ Thn & 33 & 44,00 \\
\hline $30-39$ Thn & 22 & 29,33 \\
\hline$\geq 40$ Thn & 9 & 12,00 \\
\hline PNS/TNI/Polri & 11 & 14,67 \\
\hline Wiraswasta & 18 & 24,00 \\
\hline Petani/Pedagang & 14 & 18,67 \\
\hline Tidak Bekerja & 10 & 13,33 \\
\hline IRT & 22 & 29,33 \\
\hline Diploma & 50 & 66,67 \\
\hline S1/S2 & 8 & 10,67 \\
\hline & 17 & 22,67 \\
\hline Pendidikan: SLTAan & $\mathbf{7 5}$ & $\mathbf{1 0 0}$ \\
\hline
\end{tabular}

Sumber : Hasil Penelitian, DisDukcapil Kab. Bireuen, 2020 (data diolah)

\section{b. Hasil analisis Deskriptif}

Tabel 3. Skor penilaian dan Kategori Setiap Variabel

\begin{tabular}{|c|c|c|c|c|}
\hline Variabel & & Dimensi & Skor & Kategori \\
\hline \multirow{5}{*}{$\begin{array}{l}\text { Kualitas Pelayanan } \\
\text { (X1) }\end{array}$} & 1 & Kehandalan pelayanan & 86,9 & Baik \\
\hline & 2 & Daya tanggap pegawai dalam pelayanan & 82,4 & Baik \\
\hline & 3 & Jaminan kepastian pelayanan & 83,2 & Baik \\
\hline & 4 & Perhatian pegawai pelayanan & 82,0 & Baik \\
\hline & 5 & Bukti fiisk dalam pelayanan & 79,2 & Cukup \\
\hline \multirow{3}{*}{$\begin{array}{l}\text { Sarana dan } \\
\text { Prasarana } \\
(\mathrm{X} 2)\end{array}$} & 1 & Sarana pelayanan & 85,1 & Baik \\
\hline & 2 & Prasarana pelayanan & 79,2 & Cukup \\
\hline & 3 & Media Pembelajaran & 72.0 & Cukup \\
\hline \multirow{6}{*}{$\begin{array}{l}\text { Prilaku Pegawai } \\
\text { (X3) }\end{array}$} & 1 & Orientasi Pelayanan & 83,2 & Baik \\
\hline & 2 & Integritas, & 81,1 & Baik \\
\hline & 3 & Komitmen, & 87,2 & Baik \\
\hline & 4 & Disiplin, & 82,1 & Baik \\
\hline & 5 & Kerja sama, & 84,3 & Baik \\
\hline & 6 & Kepemimpinan. & 72,8 & Cukup \\
\hline \multirow{9}{*}{$\begin{array}{l}\text { Kepuasan } \\
\text { Masyarakat } \\
\text { (Y) }\end{array}$} & 1 & Keakuratan pelayanan & 84,5 & Baik \\
\hline & 2 & Tepat sasaran & 83,5 & Baik \\
\hline & 3 & Informatif & 84,5 & Baik \\
\hline & 4 & Pelayanan cepat dan tepat. & 79,2 & Cukup \\
\hline & 5 & Pengetahuan karyawan & 85,6 & Baik \\
\hline & 6 & Memahami masyarakat. & 80,0 & Baik \\
\hline & 7 & Alternatif solusi dari setiap permasalahan & 79,7 & Cukup \\
\hline & 8 & Kepedulian pegawai & 82,1 & Baik \\
\hline & 9 & Perhatian pegawai & 77,9 & Cukup \\
\hline
\end{tabular}


Berdasarkan persepsi masyarakat (tabel 3 diatas), tentang kualitas pelayanan, mencapai 82,8 persen, tingkat kelengkapan Sarana Prasarana pelayanan dalam meningkatkan kepuasan masyarakat dalam mengurus eKTP dan Akte Kelairan di Kantor Dinas Kependudukan dan Catatan Sipil Kabupaten Bireuen masuk pada kategori baik yakni sekitar 82,1\%. Dimana dari aspek Sarana mencapai 85,1 \% dan aspek Parasarana pelayanan sebesar 79,2 \%. Penilaian atas perilaku pegawai di Kantor Dinas Kependudukan dan Catatan Sipil Kabupaten Bireuen termasuk baik pelaksanaan dan kesesuaiannya dengan yang diharapkan masyarakat, hal ini mencapai 78,5\%. Dan Kepuasan masyarakt yang mengurus atau membuat KTP-el dan Akte Kelahiran anak dilayani dengan baik di Kantor Dinas Kependudukan dan Catatan Sipil Kabupaten Bireuen, sudah menujukkan hal yang baik sekali walaupun masih bias ditingkatkan, mencapai 81,1 persen.

\section{c. Hasil Analisis Jalur}

Dengan pendekatan analisis jalur, yakni kombinasi regresi 2 variabel bebas terhadap variabel tak bebas (Kepuasan masyarakat) dan adanya hubungan kausalitas antar variabel bebas, dinyatakan dalam gambar 1 berikut:

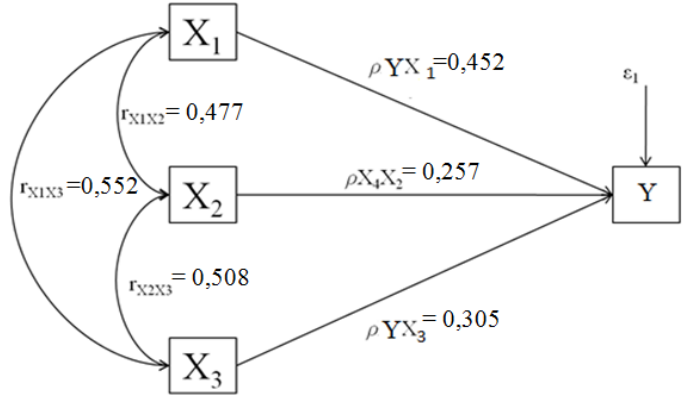

\section{Gambar 1 Diagram Jalur Penelitian}

Keterangan : $\quad \mathrm{Y}=$ Kepuasan Masyarakat

$\mathrm{X} 1$ = Kualitas pelayanan

$\mathrm{X} 2$ = Sarana dan Prasarana pelayanan

$\mathrm{X} 3$ = Perilaku pegawai

$\mathrm{r}_{\mathrm{xi}, \mathrm{xj}}=$ hubungan kausal antar variabel eksogen di ukur dengan koefisien korelasi

$\rho_{\mathrm{yxi}}=$ Nilai Koefisien Jalur (Path) yang menyatakan pengaruh langsung antar variabel eksogen terhadap variabel endogen.

\section{d. Pe,mbahasan}

\section{1). Analisis Pengaruh Variabel Kualitas Pelayanan terhadap Kepuasan Masyarakat.}

Sebagaimana dalam rancangan analisis, variabel independent dalam penelitian saling berhubungan atau kausalitas, sehingga variabel ini disebut eksogenus, dan penelitian ini meranncang pada analisis jalur (Path Analysis). Maka akan terdapat pengaruh langsung dan pengaruh tidak langsung.

Besarnya pengaruh langsung Kualitas pelayanan $\left(\mathrm{X}_{1}\right)$ terhadap Kepuasan masyarakat (Y), dinyatakan dengan besaran koefisien jalur $\left(\rho_{\mathrm{yx} 1}=0,452\right)$, Sehingga besarnya pengaruh langsung yakni $20,43 \%$.

Besarnya pengaruh tak langsung Kualitas pelayanan $\left(\mathrm{X}_{1}\right)$ terhadap Kepuasan masyarakat (Y), karena variabel kualitas pelayanan berhubungan kausal dengan variabel Sarana prasarana dan Perilaku pegawai pelayanan. Maka, dihitung pengaruh tidak langsung adalah :

- Pengaruh Kualitas pelayanan $\left(\mathrm{X}_{1}\right)$ dengan Sarana dan rasarana pelayanan $\left(\mathrm{X}_{2}\right)$ terhadap Kepuasan masyarakat (Y) sebesar: $(0,452)(0,477)(0,257) \times 100 \%=5,54 \%$

- Pengaruh Kualitas Pelayanan $\left(\mathrm{X}_{1}\right)$ dengan perilaku pegawai $\left(\mathrm{X}_{3}\right)$ terhadap Kepuasan masyarakat $(\mathrm{Y})$ sebesar: $(0,452)(0,552)(0,305) \times 100 \%=7,61 \%$

- Pengaruh total Kualitas pelayanan $\left(\mathrm{X}_{1}\right)$ terhadap Kepuasan Masyarakat $(\mathrm{Y})$, dihitung secara kumulatif dari pengaruh langsung dan tidak langsung, yakni 33,58 persen.

\section{2). Analisis Pengaruh Variabel Sarana dan Prasarana Pelayanan terhadap Kepuasan Masyarakat}

Besarnya pengaruh langsung Sarana dan Prasarana $\left(\mathrm{X}_{2}\right)$ terhadap Kepuasan masyarakat (Y), dinyatakan dengan besaran koefisien jalur $\left(\rho_{\mathrm{yx} 2}=0,257\right)$, sehingga besarnya pengaruh langsung ini adalah: $6,61 \%$. 
Besarnya pengaruh tak langsung Sarana dan Prasarana $\left(\mathrm{X}_{2}\right)$ terhadap Kepuasan masyarakat $(\mathrm{Y})$, karena terkait dengan kualitas pelayana dan perilaku pegawai pelayanan, dihitung masing-masing adalah:

- Pengaruh Sarana Prasarana $\left(\mathrm{X}_{2}\right)$ dengan kualitas pelayanan $\left(\mathrm{X}_{1}\right)$ terhadap Kepuasan masyarakat $(\mathrm{Y})$ adalah $=(0,257)(0,477)(0,452) \times 100 \%=5,54 \%$

- Pengaruh Sarana Prasarana $\left(\mathrm{X}_{2}\right)$ dengan Perilaku pegawai $\left(\mathrm{X}_{3}\right)$ terhadap Kepuasan masyarakat $(\mathrm{Y})$ adalah $=(0,257)(0,508)(0,305) \times 100 \%=3,98 \%$

- Sehingga pengaruh total dari faktor Sarana Prasarana $\left(\mathrm{X}_{2}\right)$ terhadap Kepuasan masyarakat $(\mathrm{Y})$ adalah : 16,13 persen.

\section{3). Analisis Pengaruh Variabel Perilaku pegawai terhadap Kepuasan Masyarakat}

Besarnya pengaruh langsung Perilaku pegawai $\left(\mathrm{X}_{3}\right)$ terhadap Kepuasan masyarakat $(\mathrm{Y})$, dinyatakan dengan besaran koefisien jalur ( $\left.\rho_{\mathrm{yx} 3}=0,305\right)$, Sehingga besarnya pengaruh langsung ini adalah $9,30 \%$.

Besarnya pengaruh tak langsung Perilaku pegawai $\left(\mathrm{X}_{3}\right)$ terhadap Kepuasan masyarakat $(\mathrm{Y})$, karena terkait dengan faktor kualitas pelayanan $\left(\mathrm{X}_{1}\right)$ dan Sarana Prasarana $\left(\mathrm{X}_{2}\right)$, dihitung masing-masing berikut, yaitu:

- Pengaruh perilaku pegawai $\left(\mathrm{X}_{3}\right)$ dengan kualitas pelayanan $\left(\mathrm{X}_{1}\right)$ terhadap Kepuasan masyarakat $(\mathrm{Y})$, adalah $(0,305)(0,552)(0,452) \times 100 \%=7,61 \%$

- Pengaruh perilaku pegawai $\left(\mathrm{X}_{3}\right)$ dengan Sarana dan Prasarana $\left(\mathrm{X}_{2}\right)$ terhadap Kepuasan masyarakat $(\mathrm{Y})$ adalah $(0,305)(0,508)(0,257) \times 100 \%=3,98 \%$

- Sehingga pengaruh total Perilaku pegawai $\left(\mathrm{X}_{3}\right)$ terhadap Kepuasan masyarakat $(\mathrm{Y})$, adalah jumlah pengaruh langsung dan tidak langsung, yakni : 20,89 persen.

\section{4). Analisis Pengaruh Variabel Kualitas Pelayanan, Sarana dan Prasarana pelayaanan, dan Perilaku} Pegawai terhadap Kepuasan Masyarakat

Berdasarkan pengujian model jalur dinyatakan dengan persamaaan: $Y=0,452 X_{1}+0,257 X_{2}+0,305 X_{3}+\varepsilon$ $\left(\mathrm{X}_{1}=\right.$ Kualitas pelayanan, $\mathrm{X}_{2}=$ Sarana dan Prasarana pelayanan, $\mathrm{X}_{3}=$ Perilaku pegawai, $\mathrm{Y}=$ Kepuasan masyarakat, $\mathcal{E}=$ Structural Error)

Maka dari persamaan tersebut dapat dijelaskan bahwa koefisien jalur Kualitas pelayanan $\left(\mathrm{X}_{1}\right)$ bernilai positif $(0,452)$ artinya semakin baik kualitas dalam melayani masyarakat yang membuat KTP-el dan Akte kelahiran di Kantor Dinas Kependudukan dan Catatan Sipil Kab. Bireuen, maka akan semakin meningkat Kepuasan masyarakat, dengan derajat peningkatannya termasuk cukup tinggi yakni 0,452.

Koefisien jalur Sarana dan prasarana pelayanan $\left(\mathrm{X}_{2}\right)$ bernilai positif $(0,257)$ artinya dengan cukup terjaga dan tersedianya sarana dan prasarana pelayanan yang diberikan kepada masyarakat dalam membuat KTP-el dan Akte kelahiran di Kantor Dinas Kependudukan dan Catatan Sipil Kab. Bireuen, akan dapat meningkatkan kepuasan masyarakat.

Koefisien jalur Perilaku pegawai $\left(\mathrm{X}_{3}\right)$ bernilai positif $(0,305)$ artinya apabila pegawai dalam melayanai masyarakat dinilai berprilaku dewasa dan profesional serta sopan akan berdampak positif terhadap kepuasan masyarakat yang membuat KTP-el dan Akte kelahiran di Kantor Dinas Kependudukan dan Catatan Sipil Kab. Bireuen.

Selain menguji koefisien regresi, penelitian ini juga menguji koefisien korelasi (R) dan koefisien determinasi $\left(\mathrm{R}^{2}\right)$. Koefisien korelasi bertujuan untuk melihat keeratan hubungan antara satu variabel dengan variabel lain. Sementara korelasi determinasi $\left(\mathrm{R}^{2}\right)$ mengukur seberapa jauh kemampuan variabel-variabel independen dalam menjelaskan variasi variabel dependen (Ghozali, 2012). Maka analisis koefisien korelasi dan determinasi variabel bebas (X) dengan variabel terikat (Y) yang dapat dilihat dari tabel berikut:

\section{Tabel 4. Koeisien Korelasi Simultan}

\begin{tabular}{|c|c|c|c|}
\hline R & R Square & Adjusted R Square & Std. Error of Estimate \\
\hline 0.840 & 0.705 & 0.693 & 2.66002 \\
\hline
\end{tabular}

Sumber: Data Primer, 2020 (diolah)

Hasil analisis koefisien korelasi antara kualitas pelayanan, sarana dan prasarana pelayanan dan perilaku pegawai terhadap Kepuasan masyarakat diperoleh $R$ sebesar 0,840. Artinya variabel independent memiliki keeratan yang cukup tinggi, dan berhubungan secara linier, dengan derajat hubungannya sebesar $\mathbf{0 , 8 4 0}$ terhadap variabel dependent. 
Nilai koefisien determinasi ( $\mathrm{R}$ Square) sebesar 0,705 menjelaskan bahwa kontribusi aspek kualitas pelayanan, sarana dan prasarana pelayanan dan perilaku pegawai terhadap Kepuasan masyarakat di Kantor Dinas Kepedudukan dan Catatn Sipil Kabupaten Bireuen sebesar 70,5\%. Sementara sisanya dari peran variabel yang tidak diteliti sebesar $29,5 \%$, menujukkan bahwa terdapat faktor-faktor lain yang dapat mempengaruhi variabel Kepuasan masyarakat dalam mengurus dan membuat KTP-el dan Akte Kelahiran.

\section{Simpulan (Conclusion)}

Dari hasil penelitian, pengumpulan data, observasi dan pengolahan data yang penulis lakukan, diperoleh simpulan penelitian, yakni:

Hasil analisis data secara statistik dengan pendekatan analisis jalur, menunjukkan

a). Terdapat pengaruh langsung dan tidak langsung faktor kualitas pelayanan terhadap Kepuasan masyarakat, yang mengurus dan membuat KTP-el dan Akte Kelahiran anak di kantor Dinas Kependudukan dan Catatan Sipil Kabupaten Bireuen, yakni sebesar 33,58 \%.

b). Besarnya pengaruh faktor Sarana dan prasarana peayaanan terhadap kepuasan masyarakat yang mengurus dan membuat KTP-el dan Akte Kelahiran anak di kantor Dinas Kependudukan dan Catatan Sipil Kabupaten Bireuen, yakni sebesar 16,13\%,

c). Dan pengaruh faktor perilaku pegawai terhadap kepuasan masyarakat yang mengurus dan membuat KTP-el dan Akte Kelahiran anak di kantor Dinas Kependudukan dan Catatan Sipil Kabupaten Bireuen, sebesar 20,89\%.

d). Berdasarkan ukuran koefisien determinasi sebesar 0,705 menjelaskan bahwa kontribusi aspek kualitas pelayanan, sarana dan prasarana pelayanan dan perilaku pegawai terhadap Kepuasan masyarakat di Kantor Dinas Kepedudukan dan Catatn Sipil Kabupaten Bireuen sebesar 70,5\%. Sementara sisanya dari peran variabel yang tidak diteliti sebesar $29,5 \%$, menujukkan bahwa terdapat faktor-faktor lain yang dapat mempengaruhi variabel Kepuasan masyarakat.

\section{DAFTAR PUSTAKA (References)}

1) Agus Dwiyanto, 2006, Mewujudkan Good Geovernance Melalui. Pelayanan Public. Yogyakarta: UGM Press

2) Djojowirono. 2005, Manajemen Konstruksi Edisi Keempat, Teknik Sipil, UGM, Yogyakarta.

3) Freddy, Rangkuti. 2006. Teknik Mengukur dan Strategi Meningkatkan Kepuasan. Pelanggan. Jakarta : Penerbit PT Gramedia Pustaka Utama.

4) Ghozali, Imam. 2011. Aplikasi Analisis Multivariate Dengan Program SPSS. Badan Penerbit Universitas Diponegoro. Semarang.

5) Handayaningrat, Soewarno. 2006. Pengantar studi administrasi. Jakarta: Gunung Agung.

6) Kotler, Philip and Keller, Kevin Lane, 2013, Manajemen Pemasaran, Jilid 1, Edisi. 13, Erlangga

7) Marwan Hamid, Ibrahim Sufi, Win Konadi, dan Yusrizal Akmal, 2019. Analisis Jalur Dan Aplikasi Spss Versi 25, Edisi Pertama Sefa Bumi Persada, Medan.

8) Moenir, 2010. Manajemen Pelayanan Umum di Indonesia. Jakarta: PT Bumi Aksara

9) Moenir. 2006. Manajemen Pelayanan Umum di Indonesia, Jakarta :PT. Bumi Aksara

10) Muhammad, Ali, 2010, Kesehatan Wanita, Gender dan Permasalahannya”, Nuha Medika, Yogyakarta.

11) Nirwana Sitepu, 2014. Analisis jalur, Unpad bandung

12) Nursya'bani Purnama 2006. Manajemen Kualitas, Perspektif Global, Edisi. Pertama, Ekonisia Fakultas Ekonomi.

13) Pasolong. Harbani, 2013. Teori Administrasi Publik. Alfabeta. Bandung.

14) Ratminto \& Atik Septi Winarsih. 2005. Manajemen Pelayanan. Yogyakarta Pustaka Pelajar.

15) Rangkuti, Freddy 2002, Measuring Customer Satisfaction, Penerbit PT. Gramedia Pustaka Utama

16) Robbins, Stephen P. 2003. Perilaku Organisasi. Index. Jakarta.

17) Rohmad, Zaini. 2014, Evaluasi Kinerja; Suatu Pengantar. Surakarta: UPT UNS Press

18) Sugiyono, 2016. Metode Penelitian Pendidikan Pendekatan Kuantitatif. Kualitatif. dan R\&D. Alfabeta. Bandung.

19) Tjiptono, Fandy dan Gregorius Chandra, 2012, Pemasaran Strategik. Yogyakarta,. ANDI.

20) Tjiptono, Fandy. 2007. Strategi Pemasaran. Yogyakarta : Andi Ofset.

21) Webley, Paul dan Stephan Lea, 1997. Path Analysis. Exeter UK. Depertment of Psychology, University of Exeter

22) Peraturan Pemerintah (PP) Nomor 46 Tahun 2011,

23) Permendagri 7 tahun 2019. Pasal 39 